\title{
IS ARBITRAGE PRICING THEORY IS A FAIRY TALE ?: THE EVIDENCE FROM INDONESIA WITH ORDINARY LEAST SQUARE ESTIMATION
}

\author{
Faizal Reza \\ Adisthy Shabrina Nurqamarani \\ Danna Solihin
}

University of 17 Agustus 1945 Samarinda

J1. Ir. H. Juanda No. 80, 75124, Indonesia

reza_9946@yahoo.com

\begin{abstract}
Time series analysis in financial sector has grown in popularity since the last few decades, theories about capital markets are increasingly studied since Capital Asset Pricing Model (CAPM) and Arbitrage Pricing Theory (APT) are often compared and paired with one another. The development of APT is widespread by involving many macroeconomic variables. Unfortunately there is no consensus until now. This paper aims to examine the relevance of APT in the case of Indonesia during the period 20092017 with standard multiple regression equations.

From three independent variables, only exchange rates have a significant influence on the composite stock price (IHSG) in Indonesia, while inflation and GDP have no significant effect on stock prices. $99.8 \%$ variation in stock price formation can be explained by independent variables where there is a positive relationship between exchange rate and stock price indicates a mechanism of stock price formation through strong domestic demand before fourth quarter 2016 and trade effect (export-import) after fourth quarter 2016.
\end{abstract}

Keywords: macroeconomic variable, stock price, $A P T$.

\section{INTRODUCTION}

Miskhin (2007) defines stock as securities that can generate revenues and assets for corporations. Today, in growing global economy, the relationship between stock prices and economic factors can not be avoided. This is because financial integration has a direct impact on asset price volatility, especially in the capital market. Recorded, during the global crisis of 2008 many regions in Asia and some other regions experienced a shocks in their capital markets due to shocks in macroeconomic variables. With regard to macroeconomic variables, Ozbay (2009) says that the causality relationship between stock price and macroeconomic variables remains a hotly debated topic until now by many experts. Much literature attempts to examine the causality between stock prices and macroeconomic variables that still show mixed results. Various 
methods are used by researchers in examining the causality with different data sets and methods over time.

According to Barakat et. al. (2016), there are three reasons why capital market causality and macroeconomic variables are interesting to examine: first, policy makers will be able to predict the full effect of future regulations and policies. Second, investors can make informed decisions when they understand the causality between macro variables and stock prices so can reduce risk. Third, when the public is aware of the changes that occur in the economy or financial markets, then the shock will be reduced. In modern financial literature, there are two basic theories that examine the relationship between stock returns and the factors that influence them, namely Capital Asset Pricing Model (CAPM) or Traditional Approach and Arbitrage Pricing Theory (APT). Pal and Mittal (2011) stated that since the stock market is believed to reflect the fundamentals of the economy, stock prices should be the main indicators of economic activity. According to many experts, in addition to influenced by internal factors of the company, theoretically stock prices are also influenced by several factors such as GDP, exchange rate, inflation, unemployment rate, money supply, interest rate, budget deficit, current account, etc.

In this paper we will estimate the formation of stock prices based on APT using Indonesian data over the period 2009 to 2017. The remainder of this paper is as follows: section 2 discusses briefly on the things that related to stocks and their relation to macroeconomic variables, as well as the empirical facts surrounding APT theory, section 3 discusses the research methodology, section 4 is the result and discussion, the last 5 is the conclusion.

\section{LITERATURE REVIEW}

\section{Stock Price and Macroeconomic Variable}

Stock prices can be interpreted as the value or price that formed from the interaction of demand and supply on securities or stocks based on their expectations of future corporate profits. Actually, when viewed from the factors that to construct the stock price, there are several factors that can be categorized as stock price formers are internal factors and factors that come from outside (external factors). Some fundamental factors that come from 
outside are the interest rate, this factor is an external factor from the performance of the firms. Fluctuations in interest rates relate to other investment product types such as deposits or savings. If stocks are too fluctuating then it is obviously safer for investors to invest in other forms, and vice versa. Another factor that usually affects stock prices is the exchange rate of a country against another country's currency, if the exchange rate of a country is too weak compared to foreign currency then investors tend to sell its shares and placed it in the form of other assets such as foreign currency, gold, fixed assets or any other form, thus further causing the stock price to fall. Another factor is economic growth that can be proxied through Gross Domestic Product (GDP), GDP is a measure of performance of the economy that reflects the goodness of a country's condition at a given time, good growth is a good signal for investors to gain a profit from the their asset portfolio.

Several studies have been conducted to examine the effect of economic variables on stock prices. Solnik in Hunjra et. al. (2014) examining the effects of variables like inflation, interest rates, and exchange rates on stock prices. With monthly data from nine developed countries, the United States, Germany, Britain, France, Canada, Netherland, Switzerland, Belgium and Japan have found no significant effect between changes in inflation and the interest rate expected with US stock markets. Nieh and Lee (2001) conclude different results where there is no long-term relationship between interest rates and stock prices. Fifield et. al. (2002) with their research on emerging stock markets concludes that inflation, GDP, interest rates, and money have a significant effect on the emerging stock market. Zulfa and Tan (2009) in their research using Indonesian data during the period 2003 to 2008 concluded that inflation has a positive and significant effect on composite stock price, while the interest rate of SBI has a significant negative effect on composite stock price. Gan et. al. (2006) examines the relationship between stock prices and macroeconomic variables for New Zealand, there are several economic variables including interest rates, inflation, and exchange rates. $\mathrm{He}$ concludes that although there is a longterm relationship between macro variables and stock prices, but based on 
the Granger causality test it is concluded that New Zealand stock market conditions are not a good indicator for macro condition of the country. Barakat et. al. (2016) concluded that there is a causal relationship between macroeconomic variables (CPI, exchange rate, money supply, and interest rate) on capital market indices in developing countries i.e Greece and Tunisia. Macroeconomic variables have causality relationship with stock index for Greece and Tunisia, except CPI for Tunisia.

\section{Arbitrage Pricing Theory}

There are two theories that underlie risk analysis and stock return as well as stock price movements. These two theories are Capital Asset Pricing Model Model (CAPM) and Arbitrage Pricing Theory (APT). APT was first introduced by Stephen Ross in 1976. The APT model illustrates the relationship between asset risk and return using different assumptions with CAPM. The fundamental difference between CAPM and APT is that CAPM is basically a model that takes into account only one risk factor: systematic market risk $(\beta)$. Whereas in APT, the amount of return of an asset or a securities is influenced by several factors (in this case usually the selected factor is macroeconomic variables). For example Chen et. al. (1986) identifies at least some factors that affect the return on securities, i.e inflation rate, industrial production rate, unanticipated riskdefault premium, unanticipated interest rate. Thus it can be concluded that in the CAPM, the securities return is affected by systematic risk $(\beta)$, but in APT, the return of securities is influenced by various factors. APT equation can we write:

$$
\begin{gathered}
E\left(R_{i}\right)=\alpha_{0}+\beta_{i} F_{1}+\beta_{i} F_{2}+\ldots .+\beta_{n} F_{n}+ \\
e_{i t} \ldots \ldots \ldots \ldots \ldots(2.1)
\end{gathered}
$$

Where $\mathrm{E}(\mathrm{Ri})$ is the expected rate of return of stock, $\alpha_{0}$ is a risk free rate, $\beta_{\mathrm{j}}=$ beta of specific risk factor or sensitivity of securities income $i$ to factor $k$. $\mathrm{F}$ is the factor affecting securities income, $\mathrm{e}_{\mathrm{it}}$ is random error with $i=1,2,3, \ldots, \mathrm{n}$. Since APT is an extension model of CAPM that adds macroeconomic factors to the model, in the end many researchers focus on several variables such as interest rates, inflation, GDP, industrial production growth rates, gold prices, oil prices, etc. However, one of the disadvantages of APT is that APT does not specify a particular variable 
into a model that is able to explain the return of an asset. Nguyen et. al. (2017) mentions at least there are several versions of APT construction. First, the model by Fama and French (1993) known as the Three Factor Model. This model is written in the form:

$$
\begin{gathered}
E\left(r_{i}\right)=r_{f}+\beta i_{m} E\left(r_{m}-r_{f}\right)+ \\
\beta i_{S M B} E(S M B)+
\end{gathered}
$$$$
\beta i_{H M L} E(H M L)
$$

Where, $E\left(r_{m}-r_{f}\right)$ is the excess expected market return, $\mathrm{E}(\mathrm{SMB})$ is the expected return of the factor size, $\mathrm{E}(\mathrm{HML})$ is the expected book to market equity factor. $\mathrm{E}(\mathrm{SMB})$ represents a portfolio called Small Minus Big, while E(HML) represents a portfolio called High Minus Low. In addition to the Three Factor Model by Fama and French, Chen, Novy-Marx and Zhang (2011) also developed the Three Factor Model with another version that included two additional variables outside the CAPM variable. Models by Chen, Novy-Marx and Zhang (2011) are listed as follows:

$$
\begin{gathered}
E\left(r_{i}\right)=r_{f}+\beta i_{M K T}(M K T)+\beta i_{I N V} E(I N V)+ \\
\beta i_{R O E} E(R O E) \ldots \ldots \ldots \ldots \ldots . . .(2.3)
\end{gathered}
$$

Where (MKT) is the excess expected return of the market, $\mathrm{E}(\mathrm{INV})$ is the expected return that is built from the return of the company portfolio with low investment and little return including the company with high investment. $\mathrm{E}(\mathrm{ROE})$ is the expected return built from the company's portfolio return with high equity returns and low returns from the portfolio as well as companies with low equity returns. The third model was developed by Fama and French (2015) with a Five Factor Model that accommodates the size, value, profitability, and investment patterns that result in average stock returns. They write APT with Five Factor Model as follows:

$$
\begin{gathered}
R_{i t}-R_{f t}=\alpha_{i}+b_{i}\left(R_{m t}-R_{f t}\right)+s_{i} S M B_{t}+ \\
h_{i} H M L_{t}+r_{i} R M W_{t}+c_{i} C M A_{t}+ \\
e_{i t} \ldots \ldots \ldots \ldots(2.4)
\end{gathered}
$$

Where $R_{i t}-R_{f t}$ is the difference between the return of securities $i$ in period $t, \mathrm{R}_{\mathrm{ft}}$ is risk free return, $\mathrm{RMW}$ is the difference between stock return which is diversification with strong profitability and weak profitability. While the CMA is the difference between diversified stock returns on companies with large and small investments, i.e conservative and aggressive companies. Based on Huberman and Wang (2005), estimation of $\beta$ matrix in APT at least done through 
three approaches. The first two approaches take into account the structure of the factors, while the latter is chosen arbitrarily through the judgment of the researcher. The first approach consists of an algorithmic analysis of the co variance matrix of asset return, there are two ways are the factor analysis and principal component analysis. The next way researchers usually use their judgment in selecting factors for estimation of $\beta$ matrix. Huberman and Kandel (1985a) chose indexes from small firms, one medium company, and one large company. Rosenberg, Reid and Lanstein (1984) and Fama and French (1992) also stated that stock return expectations are also related to the ratio of book-to-market equity. The third way is through the intuition of researchers in choosing the factors that determine the stock return. According to Huberman and Wang (2005), this method is used by Chen, Roll, and Ross (1986) using macroeconomic variables and financial variables such as inflation rate, industrial production growth, aggregate consumption, short-term and long-term interest rates. Finally, this third way causes many researchers adding macroeconomic variables in APT estimation. What is interesting is that regardless of what factors the researcher chooses, the results of their findings tend to indicate more satisfactory results than the CAPM.

\section{DATA AND METHODOLOGY}

The data used in this study comes from several sources i.e. from yahoo finance.com, Central Bank of Indonesia, Central Bureau of Statistics, and other relevant sources. To minimize distortions on estimates resulting from structural breaks in the 2008 global crisis, Indonesia's data from January 2009 to December 2017 were selected by comparison with some databases of the Asian Development Bank, IMF, Blombeerg and World Bank. To avoid outlines in the data we will eliminate data that is not appropriate based on the data source reports above by doing comparisons between data sources. To estimate the equation, we use standard multiple regression with the following equation:

$$
\begin{aligned}
& \mathrm{SP}_{\mathrm{t}}=\alpha_{0}+\beta_{1} \mathrm{ER}_{\mathrm{t}}+\beta_{2} \mathrm{INF}_{\mathrm{t}}+ \\
& \beta_{3} \mathrm{GDP}_{\mathrm{t}}+\varepsilon_{\mathrm{t}} \ldots \ldots \ldots \ldots \ldots \ldots . . . . . . . . . . .
\end{aligned}
$$

Where $\mathrm{SP}_{\mathrm{t}}$ is the composite stock price (IHSG) in the period $t, \mathrm{ER}_{\mathrm{t}}$ is the Rupiah exchange rate against US Dollar in period $t, \mathrm{INF}_{\mathrm{t}}$ is the inflation rate in 
period $t$, and GDP $\mathrm{G}_{\mathrm{t}}$ is Gross Domestic period $t$. The regression coefficients can Product (GDP) in constant 2010 price in be searched with the matrix of equations:

\begin{tabular}{|c|c|c|c|c|c|c|c|c|}
\hline $\mathrm{n}$ & $\sum X 1$ & $\Sigma X 2$ & $\sum \times 3$ & $\ldots$ & $\sum X n$ & b0 & & $\sum Y$ \\
\hline$\sum X 1$ & $\sum X 1^{\wedge} 2$ & $\sum X 1 \sum X 2$ & $\Sigma X 1 \Sigma X 3$ & $\ldots$ & $\sum X 1 \sum X n$ & b1 & & $\Sigma X 1 Y$ \\
\hline$\Sigma X 2$ & $\Sigma X 1 \Sigma X 2$ & $\sum \times 2^{\wedge} 2$ & $\Sigma \times 2 \sum X 3$ & $\ldots$ & $\sum X 2 \sum X n$ & b2 & $=$ & $\Sigma X 2 Y$ \\
\hline$\Sigma X 3$ & $\Sigma X 1 \sum X 3$ & $\sum \times 2 \sum X 3$ & $\sum \times 3^{\wedge} 2$ & $\ldots$ & $\sum X 3 \sum X n$ & b3 & & $\sum \times 3 Y$ \\
\hline$\cdots$ & $\ldots$ & $\cdots$ & $\ldots$ & $\cdots$ & $\cdots$ & $\cdots$ & & $\ldots$ \\
\hline$\sum X n$ & $\sum X 1 X n$ & $\sum \times 2 X n$ & $\sum \times 3 X n$ & $\ldots$ & $\sum X n^{\wedge} 2$ & bn & & $\sum \mathrm{XnY}$ \\
\hline
\end{tabular}

Using the Cramer System Equation Solution (SPL) below:

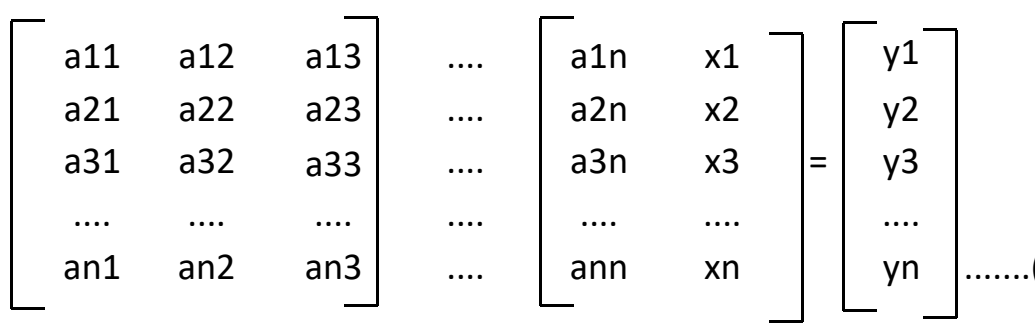

So that each regression coefficient we can find by:

$$
x_{j}=\frac{|A j|}{|A|}
$$

Where the matrix $\mathrm{Aj}$ is:

$$
\begin{aligned}
A 1 & =\left[\begin{array}{ccccc}
y 1 & \text { a12 } & \text { a13 } & \ldots & \text { a1n } \\
y 2 & \text { a22 } & \text { a23 } & \ldots & \text { a2n } \\
y 3 & \text { a32 } & \text { a33 } & \ldots & \text { a3n } \\
\ldots & \ldots & \ldots & \ldots & \ldots \\
y n & \text { an2 } & \text { an3 } & \ldots & \text { ann }
\end{array}\right] \ldots \ldots . .(3.5 a) \\
\text { A2 } & =\left[\begin{array}{ccccc}
\text { a11 } & \text { y1 } & \text { a13 } & \ldots & \text { a1n } \\
\text { a21 } & \text { y2 } & \text { a23 } & \ldots & \text { a2n } \\
\text { a31 } & \text { y3 } & \text { a33 } & \ldots & \text { a3n } \\
\ldots & \ldots & \ldots & \ldots & \ldots \\
\text { a3n } & \text { yn } & \text { an3 } & \ldots & \text { ann }
\end{array}\right] \ldots \ldots \ldots \text { (3.5b) } \\
\text { A3 } & =\left[\begin{array}{ccccc}
\text { a11 } & \text { a12 } & \text { y1 } & \ldots & \text { a1n } \\
\text { a21 } & \text { a22 } & \text { y2 } & \ldots & \text { a2n } \\
\text { a31 } & \text { a32 } & \text { y3 } & \ldots & \text { a3n } \\
\ldots & \ldots & \ldots & \ldots & \ldots \\
\text { a3n } & \text { an2 } & \text { yn } & \ldots & \text { ann }
\end{array}\right] \ldots \ldots . .(3.5 c)
\end{aligned}
$$




$$
A=\left[\begin{array}{cccc}
n & \sum X 1 & \sum X 2 & \sum X 3 \\
\Sigma X 1 & \sum X 1^{\wedge} 2 & \sum X 1 \sum X 2 & \sum X 1 \sum X 3 \\
\Sigma X 2 & \sum X 1 \sum X 2 & \sum X 2^{\wedge} 2 & \sum X 2 \sum X 3 \\
\Sigma X 3 & \sum X 2 \sum X 3 & \sum X 2 \sum X 3 & \sum X 3^{\wedge} 2
\end{array}\right]
$$

With $j=1,2, \ldots . \mathrm{n}$. While the partial correlation coefficient of equation (3.1) can be searched by the following formula:

$$
\mathrm{r}_{\mathrm{xi}, \mathrm{y}}=\frac{n \cdot\left(\sum X i Y\right)-\left(\sum X i\right)(Y)}{\sqrt{\left\{n\left(\sum X_{1}^{2}\right)\left(\sum X 1\right)^{2}\right\}\left\{n\left(Y^{2}\right)-\left(\sum Y\right)^{2}\right\}}}
$$

Where $i=1,2, \ldots, n$. $\mathrm{r}_{\mathrm{xi}, \mathrm{y}}$ is the relation of the independent variable to the dependent variable. So that we can write the coefficient of determination as follows:

$$
\mathrm{R}^{2}=(\mathrm{r})^{2}
$$

\section{FINDINGS AND DISCUSSIONS}

Before estimating the equation, all data are transformed in the form of logarithm. With normality testing, it was concluded that the residuals were normally distributed with a Jarque-Bera value of $48.5185<\chi^{2}$ tables of 124.342

Table 4.1 Regression Estimation

\begin{tabular}{ccccc}
\hline \hline \multirow{2}{*}{ Independent Variable } & \multicolumn{4}{c}{ dependent variable $=$ SP } \\
\cline { 2 - 5 } & Coeficient & StandardError & t-statistik & Prob. Value \\
\hline ER & 0,912 & 0,008 & $121,278^{*}$ & 0,000 \\
INF & 0,001 & 0,003 & 0,241 & 0,81 \\
GDP & 0,004 & 0,004 & $-1,092$ & 0,277 \\
\hline \hline
\end{tabular}

note: * significantat $\alpha=0,01$

It is seen that from three independent variables only exchange rate (ER) which have significant influence to (attached). Because of from calculation residual is normally distributed, so parametric statistics method can be applied in this case. The regression coefficient is obtained from equations (3.2) to (3.4) where the estimation results are as follows: 
inflation and GDP concluded no significant effect on stock price formation during the study period. Theoretically, the relationship between exchange rate and stock price is negative, if the value of the domestic currency depreciates against foreign currencies, it leads to an increase in exports and then will generate profits for the company, high profits will be increase stock prices in the stock market.
However, based on Indonesia's data, the rise in the exchange rate is also followed by a rise in stock prices. Figure 4.1 describe the development of stock prices and exchange rates during 2009-2017. The positive relationship of estimates is actually an early indication that the appreciation of the US Dollar against the Rupiah has led to more profit growth due to export-oriented companies.

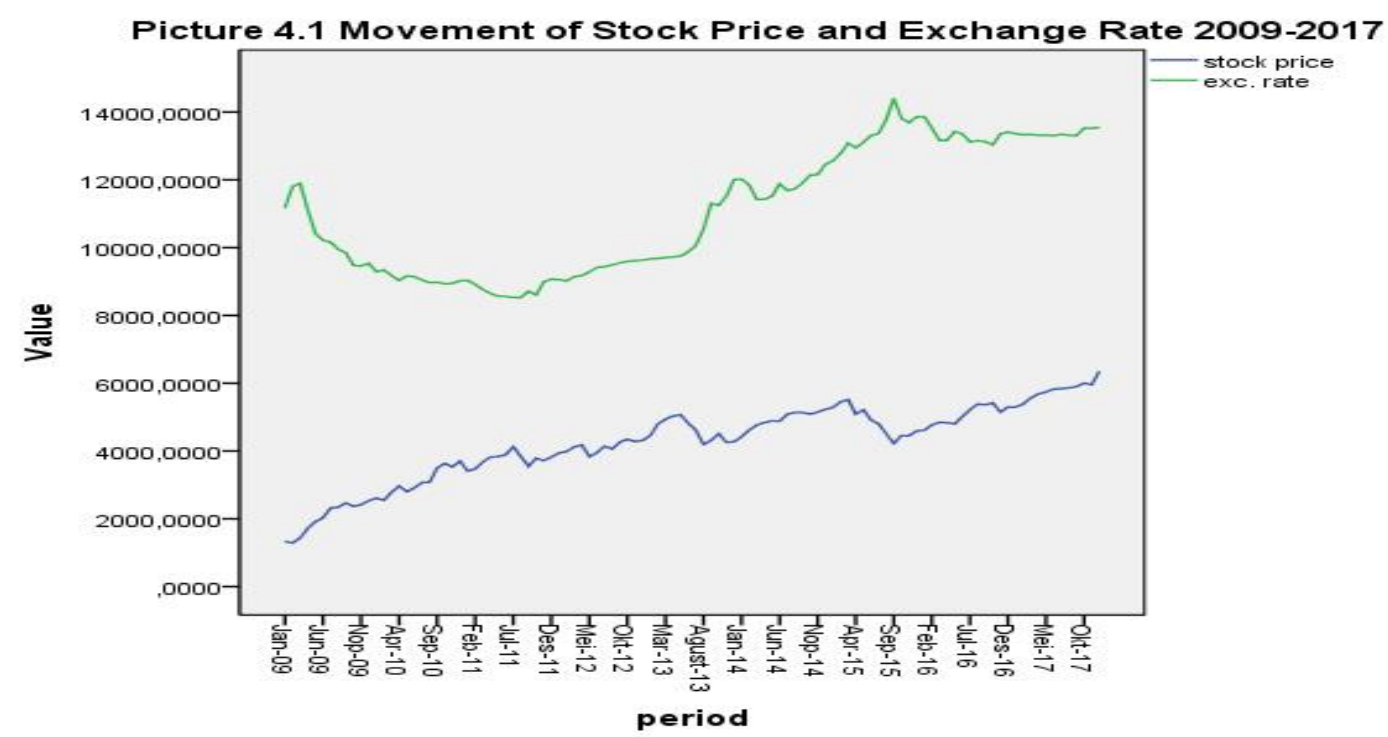

Source: Data of research

But this is not entirely true because the increase in profit from the company is caused by strong domestic demand (domestic oriented strategy) that does not correlate perfectly with the exchange rate especially before the fourth quarter of 2016. Based on the data in 2016, a decline in global economic performance caused by several reasons including declining world economic growth, falling prices for energy and non energy commodities, uncertainty in global financial market, unpredictable geopolitical movements such as Brexit in Europe, Trump effect and economy re-balancing strategy by China before the end of 2016. Table 4.2 describes the prices of export commodities in Indonesia. 
Table 4.2 Indonesia Export Commodity Price

\begin{tabular}{|c|c|c|c|c|c|c|c|c|}
\hline \multirow{2}{*}{ Commodity } & \multirow{2}{*}{ Unit } & \multirow{2}{*}{2014} & \multirow{2}{*}{2015} & \multicolumn{4}{|c|}{2016} & \multirow{2}{*}{2016} \\
\hline & & & & I & II & III & IV & \\
\hline Coal & USD/Metric Ton & 75,3 & 56,8 & 45,4 & 48,3 & 59,8 & 84 & 59,4 \\
\hline Copper & USD/Metric Ton & 6827,8 & 5506,8 & 4688,2 & 4727,7 & 4798 & 5293,6 & 4878,1 \\
\hline Nickel & USD/Metric Ton & 16971,3 & 11924 & 8558 & 8854,8 & 10337,6 & 10829,4 & 9647,8 \\
\hline Palm Oil & MYR/Metric Ton & 2413,7 & 2190,7 & 2467,4 & 2597,5 & 2628,7 & 2932,5 & 2657,9 \\
\hline Rubber & USD/Kg & 223,3 & 178,2 & 140 & 183,8 & 173,7 & 192,7 & 172,9 \\
\hline Tin & USD/Metric Ton & 21877,4 & 16041,9 & 15491,3 & 16863 & 18587,3 & 20680,9 & 17918,2 \\
\hline Aluminium & USD/Metric Ton & 1895,6 & 1684,4 & 1515,3 & 1581,9 & 1635 & 1709,5 & 1611 \\
\hline Coffe & USD/Pound & 196,3 & 151,6 & 130,4 & 136,7 & 153 & 157,3 & 144,4 \\
\hline
\end{tabular}

Source: Bank Indonesia, the figures in italics are the turning points of export commodity prices.

From Table 4.2 it appears that export commodity prices experienced a turning point in the fourth quarter of 2016 where prices began to show a change. What is happening in developed countries is inversely related to financial market conditions in developing countries, although on the one hand there is appreciation of the Rupiah due to the flow of capital into developing countries including Indonesia and India, but due to investor anticipation in the stock market in developed countries that causing Rupiah appreciation does not give a significant negative impact on the trading sector in Indonesia, especially before the fourth quarter of 2016. Inflation tends to stabilize in developing countries $4.7 \%$ range causes GDP's developing countries are higher compared to developed countries. Bank Indonesia reports that this higher yield has become a factor in attracting capital inflow to developing countries especially after 2013. Although there is a capital outflow, but the numbers are relatively small, this is why there is a positive correlation between the exchange rate and the stock price, although the Rupiah appreciated.Roache (2012) reports that every $1 \%$ increase in US economic growth will lead to an increase in metal commodity prices (tin, nickel, copper, aluminum) by $6-9.8 \%$ and $9.9 \%$ for oil. Empirical data shows that the exchange rate hypothesis against stock prices is valid before 2015 where if the Dollar appreciates will result the decline in global commodity prices. $1 \%$ increase The dollar against the domestic currency led to a $3.45 \%$ drop for oil price and 1.7 - 3.7\% for the metal group price. But from the beginning of 2015 this pattern changed where the negative relationship became positive, this means 
the US Dollar not necessary to translate into lower commodity prices to boost exports and corporate profits.

Roache findings (2012) also occur in China but the difference is the appreciation of the Chinese Yuan does not result in the turning point like US dollar against global commodity prices. The stability of this mechanism occurs because China always keeps its import policy from 1990 to the present time by importing more commodities than the US and even the average of the world. Since importer countries experience uncertainty in export-import policies, the relationship between exchange rate and stock price will be difficult to ascertained. With the right policy, we conclude that theories that explain the relationship between exchange rate and stock price through trade (export-import) will not experience distortion. An important finding that we may point out in this paper that the change in sign in the exchange rate estimate relative to the foreign currency is very sensitive to the trading partner's country's conduct on how they are taking policy. Finally, APT contains not only the structural factors, macroeconomic factors, but we also suspect that include the agency's relative behavior that difficult to measure.Simultaneously the effect of exchange rate, inflation, and GDP on stock price formation is significant at level $1 \%$ with $\mathrm{F}_{\text {sta }}$ value. equal to $16011,516$.

Table 4.3 Correlation Coeficient dan Determination Coeficient

\begin{tabular}{lccc}
\hline \hline Independent Variable & $\begin{array}{c}\text { ExchangeRate } \\
\text { (ER) }\end{array}$ & $\begin{array}{c}\text { Inflation } \\
\text { (INF) }\end{array}$ & GDP \\
\hline$r$ (parsial) & 0,997 & 0,024 & $-0,107$ \\
R2 & & 0,998 & \\
Adj. R2 & & 0,998 & \\
$r$ (simultan) & & 0,999 & \\
\hline \hline
\end{tabular}

note: dependent variable $=$ SP

From the coefficient of determination we can conclude that the change variation of stock price can be explained by the changes variation of the independent variable of $99.8 \%$, while the remaining $0.2 \%$ is explained by other factors that out the model.
While the correlation between all independent variables to the dependent variable is 0.999 . This means that there is a very strong relationship between dependent and independent variables. To ensure the accuracy of estimates and the presence of BLUE properties, we 
will ultimately examine whether our estimates fulfill the classical assumptions, particularly are free from auto-correlation and heteroscedasticity problems.

After doing the Cohcrane Orcutt iteration, we find that equation (3.1) is free from the autocorrelation problem in the residual observation. This is evidenced sugested by the DurbinWatson test value of 1.994. This value between the dU value of 1.7437 and the $4-\mathrm{dU}$ value of 2.2563 (the results are attached). The assumption of homocedasticity that must be exist in the time series estimation we do with the Breusch-Pagan-Godfrey Heteroskedasticity (BPG) test. The test results concluded that there were no problem with heteroscedasticity where the value of $\chi^{2}$ of $56.2131<\chi^{2}$ table at $5 \%$ level of 135,807 (calculation attached). This means that our residual are free from auto-correlation problems and also have the

same variance in each observation. After making sure there is no residual problem, in this paper the linearity test between independent variables to the dependent variable is based solely on the grand theory between the dependent variable and the explanation variables (see Sumodiningrat, 2010). Finally, need to deeper investigations using other time series methods to obtain an in-depth explanation for role of determinant variables within APT, this is a research agenda that provides widespread space for other studies.

\section{CONCLUSION}

APT applications have been widely used in finance sector, many researchers are still trying to identify the factors that influence and correlate with stock prices.

Too many factors can be added in the APT, with the case of Indonesia during 2009-2017 we concluded that exchange rate has an impact on the composite stocks price in Indonesia. With standard multiple regression even though $\mathrm{R}^{2}$ criteria are satisfactory, there is not enough evidence to suggest that inflation and GDP have a significant effect on stock price formation.

Finally, APT need to be investigated by other advanced time series method in order to obtain deeper conclusions in this field. 


\section{REFERENCE}

Barakat, Mahmoud Ramadan, Sara. H. Elgazzar, M. Hanafy, 2016. "Impact of Macroeconomic Variables on Stock Market: Evidence from Emerging Market", International Journal of Economicsand Finance, 8 (1): 195-207.

Chen, Nai-Fu, Richard Roll, and Stephen Ross, 1986. "Economic Forces and Stock Market", The Journalof Business, 59 (3): 383403.

Chen, L., Novy-Mark, R., and Zhang, L., 2010. "An Alternative Three Factor Model”, Working Paper, University of Rochester.

Fama, E., and French, K., 2015. "A Five Factor Asset Pricing Model", Journal of Finance Economics, 116 (1): 1-22.

Fifield, S.G.M., D.M. Power, and Cd. Sinclair, 2002. "Macroeconomic Factors and Share Returns: An Analysis Using Emerging Market Data", International Journal of Finance and Economics, 7: 51-62.

Gan, Christopher, et. al., 2006. "Macroeconomic Variables and Stock Market Interactions: New Zealand Evidence", Investment Managementand Financial Innovation, 3 (4): 89-101.

Huberman, Gur, and Zhenyu Wang, 2015. "Arbitrage Pricing Theory", The New Palgrave Dictionary of Economics, 2nd Edition, S. N. Durlaufand L. E. Blume (eds), Palgrave Macmillan.
Hunjra, Ahmed Imran et. al., 2014. "The Impact of Macroeconomic Variables on Stock Price in Pakistan", Munich Personal RePEcArchive (MPRA)No. 60791.

Mishkin, F., 2007. The Economic of Money, Banking, and Financial Market, Pearson, Boston.

Nguyen, et. al., 2017. "The Capital Asset Pricing Model and The Arbitrage Pricing Theory", Financial Risk, MSA 400.

Nieh, C. C., and Lee, C. F.,2001. "Dynamic Relationship Between Stock Price and Exchange Rate for G-7 Countries", The Quarterly Review of Economics and Finance, 41: 477-490.

Ozbay, E., 2009. "The Relationship Between Stock Return and Macroeconomic Factors: Evidence for Turkey", Financial Analysis and Fund Management, Dissertation in University of Exeter.

Pal, K., and Mittal R., 2011. "Impact of Macroeconomic Indicators on Indian Capital Market", Journal of Risk Finance, 12(2): 84-97.

Roache, Shaun K., 2012. "China Impact on the Commodity Market", IMF Working Paper 12/15.

Rosenberg, B., Reid, K., and Lanstein R., 1984. "Persuasive Evidence of Market Inefficiency", Journal of Portfolio Management, 11:9-17.

Sumodiningrat, Gunawan, 2010. Ekonometrika Pengantar, BPFE, Yogyakarta. 
Zulfa, Ahmad, dan Juhono Tan, 2009.

"Analisa Pengaruh Inflasi dan

Bunga SBI Terhadap IHSG di

BEI", Jurnal Dinamika Ekonomi

dan Bisnis, 6 (2): 159-170. 